J. Phys. Chem., Article

\title{
Direct Evidence for Li Ion Hopping Conduction in Highly Concentrated Sulfolane-Based Liquid Electrolytes
}

\author{
Kaoru Dokko,${ }^{\dagger}$ Daiki Watanabe, ${ }^{\dagger}$ Yosuke Ugata, ${ }^{\dagger}$ Morgan L. Thomas, ${ }^{\dagger}$ Seiji Tsuzuki, ${ }^{\dagger}$ Wataru \\ Shinoda,$^{\S}$ Kei Hashimoto, ${ }^{\dagger}$ Kazuhide Ueno, ${ }^{\dagger}$ Yasuhiro Umebayashi, " and Masayoshi \\ Watanabe ${ }^{\dagger, *}$
}

Department of Chemistry and Biotechnology, Yokohama National University, 79-5 Tokiwadai, Hodogaya-ku, Yokohama 240-8501, Japan

$¥$ Research Center for Computational Design of Advanced Functional Materials (CD-FMat), National Institute of Advanced Industrial Science and Technology (AIST), Tsukuba Central 2, 1-1-1 Umezono, Tsukuba, Ibaraki 305-8568, Japan

$\S$ Department of Materials Chemistry, Nagoya University, Furo-cho, Chikusa-ku, Nagoya 4648603, Japan

" Graduate School of Science and Technology, Niigata University, 8050 Ikarashi, 2-no-cho, Nishi-ku, Niigata 950-2181, Japan

*To whom correspondence should be addressed. E-mail: mwatanab@ynu.ac.jp 


\begin{abstract}
We demonstrate that $\mathrm{Li}^{+}$hopping conduction, which cannot be explained by conventional models i.e. Onsager's theory and Stokes' law, emerges in highly concentrated liquid electrolytes composed of $\mathrm{LiBF}_{4}$ and sulfolane (SL). Self-diffusion coefficients of $\mathrm{Li}^{+}$ $\left(D_{\mathrm{Li}}\right), \mathrm{BF}_{4}^{-}\left(D_{\mathrm{BF} 4}\right)$, and $\mathrm{SL}\left(D_{\mathrm{SL}}\right)$ were measured with pulsed field gradient NMR. In the concentrated electrolytes with molar ratios of $\mathrm{SL} / \mathrm{LiBF}_{4} \leq 3$, the ratios $D_{\mathrm{SL}} / D_{\mathrm{Li}}$ and $D_{\mathrm{BF} 4} / D_{\mathrm{Li}}$ become lower than 1 , suggesting faster diffusion of $\mathrm{Li}^{+}$than $\mathrm{SL}$ and $\mathrm{BF}_{4}^{-}$, and thus the evolution of $\mathrm{Li}^{+}$hopping conduction. X-ray crystallographic analysis of the $\mathrm{LiBF}_{4}: \mathrm{SL}(1: 1)$ solvate revealed that the two oxygen atoms of the sulfone group are involved in bridging coordination of two different $\mathrm{Li}^{+}$ions. In addition, the $\mathrm{BF}_{4}{ }^{-}$anion also participates in bridging coordination of $\mathrm{Li}^{+}$. Raman spectra of the highly concentrated $\mathrm{LiBF}_{4}-\mathrm{SL}$ solution suggested that $\mathrm{Li}^{+}$ions are bridged by $\mathrm{SL}$ and $\mathrm{BF}_{4}^{-}$even in the liquid state. Moreover, detailed investigation along with molecular dynamics simulations suggests that $\mathrm{Li}^{+}$exchanges ligands ( $\mathrm{SL}$ and $\mathrm{BF}_{4}^{-}$) dynamically in the highly concentrated electrolytes, and $\mathrm{Li}^{+}$hops from one coordination site to another. The spatial proximity of coordination sites, along with possible domain structure, is assumed to enable $\mathrm{Li}^{+}$hopping conduction. Finally, we demonstrate that $\mathrm{Li}^{+}$hopping suppresses concentration polarization in Li batteries, leading to increased limiting current density and improved rate capability compared to the conventional concentration electrolyte. Identification and rationalization of $\mathrm{Li}^{+}$ion hopping in concentrated $\mathrm{SL}$ electrolytes is expected to trigger a new paradigm of understanding for such unconventional electrolyte systems.
\end{abstract}




\section{Introduction}

Ion conduction in dilute electrolyte solutions containing excess solvent is well explained by conventional solution theory. ${ }^{1}$ In electrolyte solutions containing excess solvent, the salt dissociates into its component ions, and the ions are stabilized by solvation. The solvated ions then diffuse and migrate in the solution, via the so-called vehicular mechanism. Specifically, Onsager's theory well describes the ion conduction in dilute strong electrolyte solutions. The ionic conductivity can be related to the diffusion coefficients of the ions by the Nernst-Einstein equation. The diffusion coefficients of ions are described by the StokesEinstein equation (valid for diffusion of species in a homogeneous medium). Therein, the diffusion coefficients of the ions are proportional to $1 / \eta\left(\eta\right.$ : viscosity) and $1 / r_{h}\left(r_{h}\right.$ : hydrodynamic radius of the ionic species). In the case of electrolytes composed of Li salt and aprotic solvents, the $\mathrm{Li}^{+}$ion is solvated by aprotic solvent molecules, and the solvated $\mathrm{Li}^{+}$, i.e., $\left[\mathrm{Li}(\text { solvent })_{\mathrm{x}}\right]^{+}$, is formed in solution. ${ }^{2}$ The solvated $\mathrm{Li}^{+}$ion then diffuses in the solution, and therefore, the effective hydrodynamic radius of $\mathrm{Li}^{+}$becomes much larger than the typical crystallographic ionic radius of $\mathrm{Li}^{+} .3$

Organic electrolytes containing Li salts are employed practically in Li-ion batteries (LIBs), and their physicochemical properties have been widely studied. ${ }^{4-5}$ Commonly used electrolytes for LIBs contain ca. $1 \mathrm{~mol} \mathrm{dm}^{-3} \mathrm{Li}$ salt (typically, $\mathrm{LiPF}_{6}$ ), because the ionic conductivity becomes highest at $\sim 1 \mathrm{~mol} \mathrm{dm}^{-3}$ (vide infra). However, highly concentrated electrolytes containing Li salt with concentrations of greater than $3 \mathrm{~mol} \mathrm{dm}^{-3}$, termed "solventin-salt" or "superconcentrated" electrolytes, have recently attracted much attention owing to their unique physicochemical properties and their potential applications to next generation batteries. ${ }^{6-11}$ The highly concentrated electrolytes are known to possess wide electrochemical windows and expected to be used in high voltage batteries. ${ }^{12-14}$ Here, we note that compared with other aprotic solvents, sulfones are known to have higher oxidative stability and have been 
investigated as electrolyte solvents for LIBs. ${ }^{15-22}$ In addition, highly reversible Li metal deposition/dissolution in the highly concentrated sulfone-based electrolytes were reported recently. ${ }^{23}$ Such electrolytes are expected to be suitable for development of high-voltage and high-energy-density batteries..$^{22-23}$

In this study, we investigated the transport properties of highly concentrated electrolytes composed of Li salts and sulfolane (SL). In the highly concentrated electrolytes, almost all solvent molecules in solution are involved in the solvation of $\mathrm{Li}^{+}$ion, and thus the proportion of uncoordinated (free) solvent molecules is negligible. Moreover, the solvated $\mathrm{Li}^{+}$ ions are always in close proximity to the anions, leading to strong electrostatic interactions between $\mathrm{Li}^{+}$and anions. This situation is completely different from that of dilute electrolyte solution, and thus Onsager's theory and Stokes law cannot reasonably be applied to the highly concentrated electrolytes. We found that $\mathrm{Li}^{+}$hopping conduction, akin to the Grotthuss mechanism in protic media, occurs in the highly concentrated SL-based electrolytes. An ion conduction mechanism in the solvent-in-salt electrolytes is proposed based on the solvation structure of $\mathrm{Li}^{+}$and molecular dynamics (MD) simulations. Finally, we demonstrate that the $\mathrm{Li}^{+}$hopping suppresses the concentration polarization in $\mathrm{Li}$ batteries.

\section{Results and Discussion}

Transport properties. The ionic conductivity $(\sigma)$ and viscosity $(\eta)$ of $\mathrm{LiBF}_{4}-\mathrm{SL}$ electrolyte as a function of concentration are shown in Figure 1a and Table S1 (Supporting Information). The ionic conductivity of $\mathrm{LiBF}_{4}-\mathrm{SL}$ electrolyte increases with increasing concentration of $\mathrm{LiBF}_{4}$ up to $\sim 1 \mathrm{~mol} \mathrm{dm}^{-3}$, because the charge carrier density increases as concentration increases. A further increase in concentration leads to a decrease in ionic conductivity due to the increase in viscosity of the electrolyte solutions, which impedes the mobility of each component species. Figure 1b shows the self-diffusion coefficients of $\mathrm{Li}^{+}$ 
$\left(D_{\mathrm{Li}}\right), \mathrm{BF}_{4}^{-}\left(D_{\mathrm{BF} 4}\right)$, and SL $\left(D_{\mathrm{SL}}\right)$ measured using pulsed field gradient (PFG) NMR. At around a concentration of $1 \mathrm{~mol} \mathrm{dm}^{-3}$, the relative order of self-diffusion coefficients is as follows: $D_{\mathrm{SL}}>D_{\mathrm{BF} 4}>D_{\mathrm{Li}}$, as is the case for conventional organic electrolytes for LIBs. ${ }^{24-25}$ This is because the $\mathrm{Li}^{+}$is solvated by $\mathrm{SL}$ in the electrolyte and forms $\left[\mathrm{Li}(\mathrm{SL})_{x}\right]^{+}$complexes. According to the Stokes-Einstein equation, the diffusion coefficient of each species is proportional to $1 / \eta$ and $1 / r_{\mathrm{h}}$. The $r_{\mathrm{h}}$ of the solvated $\mathrm{Li}^{+},\left[\mathrm{Li}(\mathrm{SL})_{x}\right]^{+}$, is larger than those of the free SL and the $\mathrm{BF}_{4}^{-}$ anion. It should be noted that NMR could not distinguish the free SL and the bound SL in the $\left[\mathrm{Li}(\mathrm{SL})_{x}\right]^{+}$complex, suggesting that the $\mathrm{Li}^{+}$exchanges ligands, i.e., $\mathrm{SL}$, rapidly in the electrolyte. This is because the lifetime of monodentate-type solvents in the first solvation shell of $\mathrm{Li}^{+}$is in the order of $10^{-9} \mathrm{~s},{ }^{2,26}$ while the time scale for NMR measurements is $\sim 10^{-4}-10^{-2}$ s. Therefore, the measured $D_{\mathrm{SL}}$ is the average value of free and coordinated SL molecules. At concentrations higher than $3 \mathrm{~mol} \mathrm{dm}^{-3}$, the viscosity increases dramatically with the $\mathrm{LiBF}_{4}$ concentration, and the self-diffusion coefficient of each species was one order of magnitude lower than that in $1 \mathrm{~mol} \mathrm{dm}^{-3}$ solution. Although the mobility of each species was low, a surprising phenomenon was observed. Figure 1c shows the ratios of self-diffusion coefficients $D_{\mathrm{SL}} / D_{\mathrm{Li}}$ and $D_{\mathrm{BF}} / D_{\mathrm{Li}}$ as a function of concentration. Both the $D_{\mathrm{SL}} / D_{\mathrm{Li}}$ and $D_{\mathrm{BF}} / D_{\mathrm{Li}}$ decrease upon increasing the $\mathrm{LiBF}_{4}$ concentration (decreasing the molar ratio of $\mathrm{SL} / \mathrm{LiBF}_{4}$ ). The decrease in $D_{\mathrm{BF} 4} / D_{\mathrm{Li}}$ indicates that the transference number of $\mathrm{Li}^{+}\left(t_{\mathrm{Li}+}\right)$ increases with $\mathrm{LiBF}_{4}$ concentration in the electrolyte solution. In the concentrated electrolytes with molar ratios of $\mathrm{SL} / \mathrm{LiBF}_{4} \leq 3$, the $D_{\mathrm{SL}} / D_{\mathrm{Li}}$ and $D_{\mathrm{BF} 4} / D_{\mathrm{Li}}$ are below unity, suggesting that $\mathrm{Li}^{+}$diffuses faster than the $\mathrm{SL}$ molecule and $\mathrm{BF}_{4}^{-}$anion. Similar results were obtained for the SL-based highly concentrated electrolytes containing other Li salts, such as $\mathrm{LiClO}_{4}$ and $\mathrm{LiN}\left(\mathrm{SO}_{2} \mathrm{~F}\right)_{2}(\mathrm{Li}[\mathrm{FSA}])$ (Figures S1 and S2, and Tables S2 and S3, Supporting Information). Namely, $D_{\mathrm{Li}}$ is higher than $D_{\mathrm{SL}}$ in these electrolyte solutions when the molar ratio of SL/Li salt is lower than 3. Although unfortunately, the diffusivity of $\mathrm{ClO}_{4}^{-}$in the $\mathrm{LiClO}_{4}-\mathrm{SL}$ electrolyte could not be 
measured using the PFG-NMR apparatus employed in this study, we could also confirm that $\mathrm{Li}^{+}$diffuses faster than the $[\mathrm{FSA}]^{-}$anion in the highly concentrated Li[FSA]-SL electrolyte. Very recently, Alvarado et al. also reported that $\mathrm{Li}^{+}$diffuses faster than $\mathrm{SL}$ and the anion in highly concentrated Li[FSA]-SL solutions, ${ }^{22}$ and this agrees well with our observation (Figure S2). These results suggest that the Stokes-Einstein equation is no longer valid for the $\left[\mathrm{Li}(\mathrm{SL})_{x}\right]^{+}$ complex cation in the highly concentrated Li salt-SL solutions. In general, the coordination number of $\mathrm{Li}^{+}$in electrolyte solutions is $4-5 .{ }^{27}$ The fraction of free solvent (SL) in the solution is lowered with increasing Li salt concentration. In this situation, not only SL but also $\mathrm{BF}_{4}{ }^{-}$are assumed to be coordinated to $\mathrm{Li}^{+}$, in other words, aggregates (AGGs) such as $\left[\mathrm{Li}_{x}(\mathrm{SL})_{\mathrm{y}}\left(\mathrm{BF}_{4}\right)_{z}\right]^{x-z}$ (where $x=1$ or more) might be formed in the electrolytes. We undertook detailed analyses (vide infra) of the solvation structure in order to understand the appearance of $\mathrm{Li}^{+}$ion hopping in these concentrated solutions. 

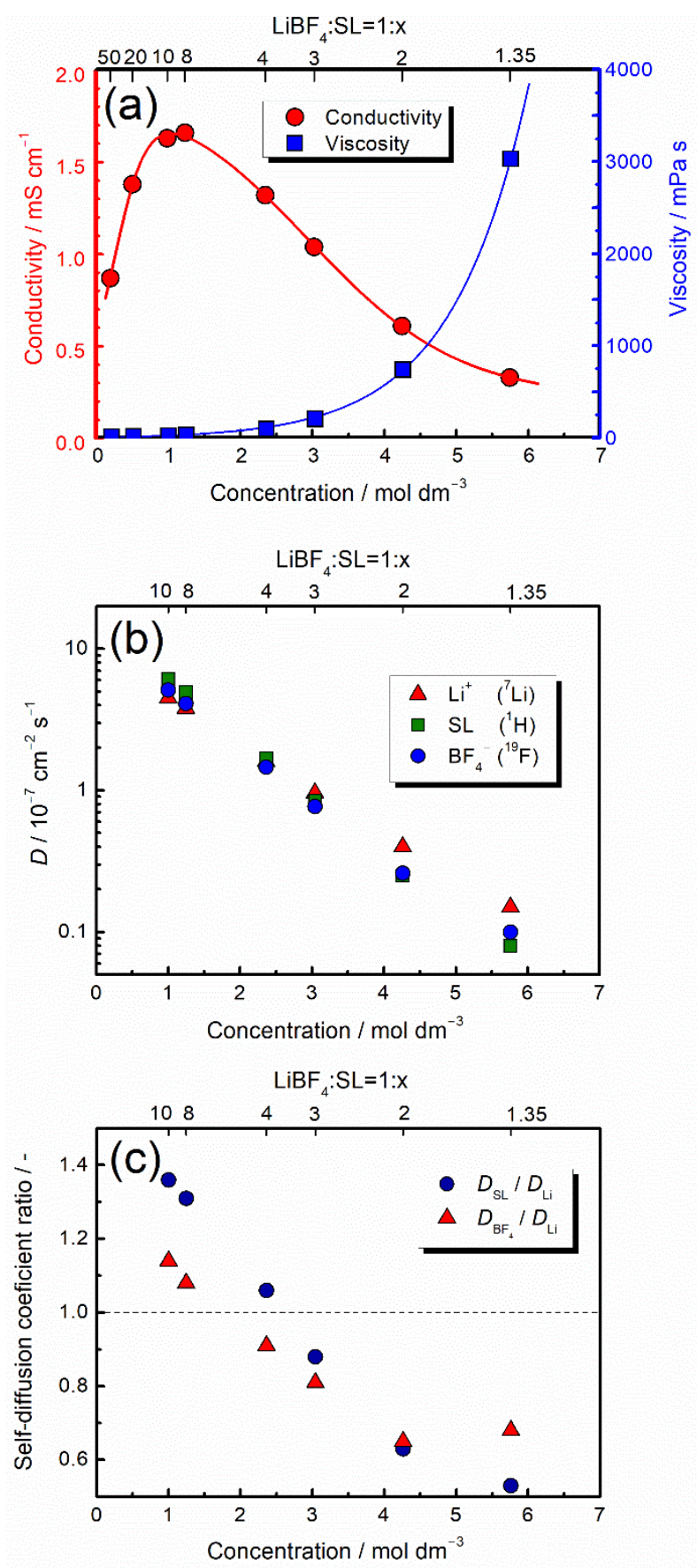

Figure 1. (a) Ionic conductivity and viscosity (lines are a guide for the eye), (b) self-diffusion coefficients of $\mathrm{Li}^{+}\left(D_{\mathrm{Li}}\right), \mathrm{BF}_{4}^{-}\left(D_{\mathrm{BF} 4}\right)$, and $\mathrm{SL}\left(D_{\mathrm{SL}}\right)$, and (c) ratios of self-diffusion coefficients $D_{\mathrm{SL}} / D_{\mathrm{Li}}$ and $D_{\mathrm{BF} 4} / D_{\mathrm{Li}}$ of $\mathrm{LiBF}_{4}-\mathrm{SL}$ electrolytes at $30^{\circ} \mathrm{C}$.

Solvation structure. Differential scanning calorimetry (DSC) thermograms, and the resulting plot of glass transition temperatures $\left(T_{\mathrm{g}}\right)$ and melting points $\left(T_{\mathrm{m}}\right)$ of binary mixtures of $\mathrm{LiBF}_{4}$ and SL are shown in Figure S3. The melting point $\left(T_{\mathrm{m}}\right)$ of pure SL is $27.5{ }^{\circ} \mathrm{C}$, and the $T_{\mathrm{m}}$ of the mixture decreases as the mole fraction of $\mathrm{LiBF}_{4}$ increases. The highly 
concentrated mixtures of $\mathrm{LiBF}_{4}: \mathrm{SL}=1: 2$ and 1:3 are glass forming liquids and melting points were not observed. These two mixtures maintain a liquid state at room temperature. The mixture of $\mathrm{LiBF}_{4}: \mathrm{SL}=1: 1$ can be crystallized, and has a $T_{\mathrm{m}}$ of $39.7^{\circ} \mathrm{C}$. The crystal structure of the $\mathrm{LiBF}_{4}: \mathrm{SL}=1: 1$ solvate was analyzed using single crystal X-ray diffraction (Figure $\mathbf{S 4}$ and Table S4). In the crystal, the coordination number of $\mathrm{Li}^{+}$is 4 , as shown in Figure $2 \mathrm{a}$. The two oxygen atoms of a single SL molecule are involved in the bridging coordination of two different $\mathrm{Li}^{+}$ions. In addition, the $\mathrm{BF}_{4}^{-}$anion also participates in the bridging coordination of two $\mathrm{Li}^{+}$ ions. For comparison, the crystal structures of solvates of $\mathrm{Li}[\mathrm{FSA}]-\mathrm{SL}$ and $\mathrm{LiClO}_{4}-\mathrm{SL}$ were also determined. Li[FSA] also forms a stable solvate with SL in a $1: 1$ molar ratio $\left(T_{\mathrm{m}}=75^{\circ} \mathrm{C}\right)$ (Figure S5), and in the crystal the SL molecule bridges $\mathrm{Li}^{+}$ions (Figure S6 and Table S5), similar to the case of the $\mathrm{LiBF}_{4}: \mathrm{SL}=1: 1$ crystal. In contrast, rather than the 1:1 solvate observed for $\mathrm{LiBF}_{4}, \mathrm{LiClO}_{4}$ forms a solvate with $\mathrm{SL}$ in a $1: 2$ molar ratio $\left(T_{\mathrm{m}}=55{ }^{\circ} \mathrm{C}\right)$ (Figure $\mathbf{S 7}$ ), despite the fact that both the $\mathrm{BF}_{4}^{-}$and $\mathrm{ClO}_{4}^{-}$anions have a tetragonal geometry and similar anion size. ${ }^{28-29}$ Interestingly, in the $\mathrm{LiClO}_{4}: \mathrm{SL}=1: 2$ crystal (Figure $\mathbf{S 8}$ and Table S6), 50\% of SL molecules act as simple monodentate ligands for $\mathrm{Li}^{+}$, and the remaining $50 \%$ of $\mathrm{SL}$ molecules bridge different $\mathrm{Li}^{+}$ions. The $\mathrm{ClO}_{4}{ }^{-}$anion also participates as a monodentate ligand in the coordination of $\mathrm{Li}^{+}$(Figure $2 \mathbf{b}$ ). 
(a) $\mathrm{LiBF}_{4}: \mathrm{SL}=1: 1$

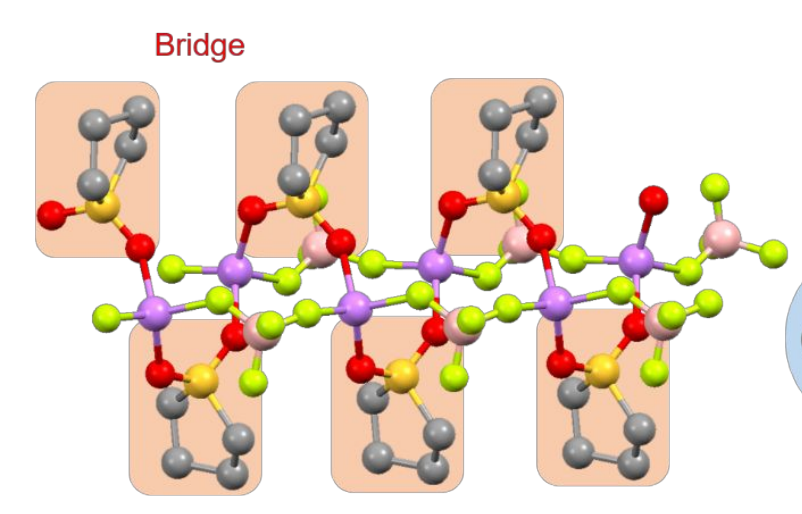

(b) $\mathrm{LiClO}_{4}: \mathrm{SL}=1: 2$

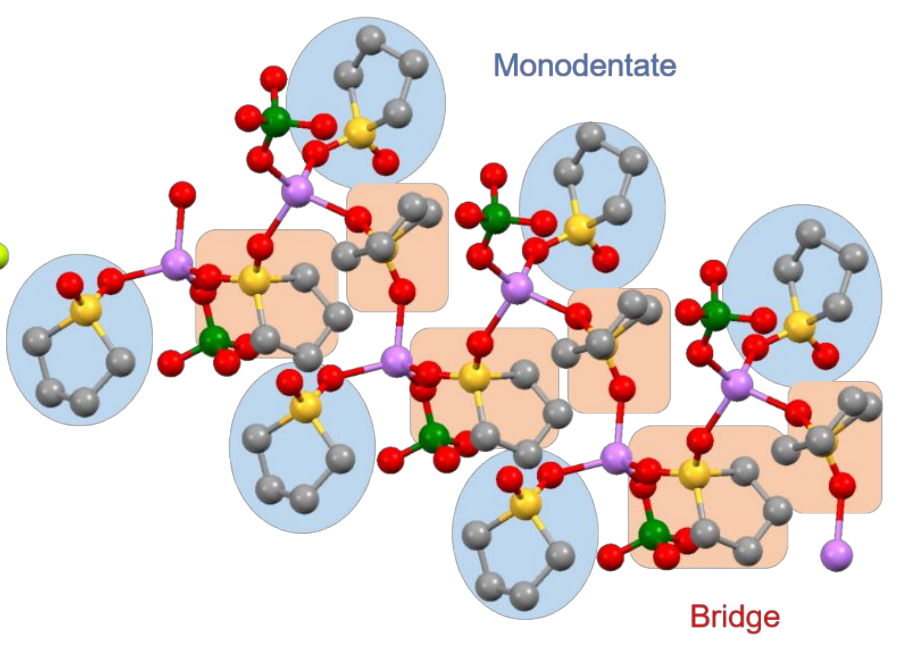

Figure 2. Ball and stick models for $\mathrm{LiBF}_{4}: \mathrm{SL}=1: 1$ (a) and $\mathrm{LiClO}_{4}: \mathrm{SL}=1: 2$ (b) crystals. Hydrogen atoms are not shown. Purple, Li; red, O; gray, C; yellow, S; light green, F; pink, B; green, $\mathrm{Cl}$. The crystallographic information file (cif) for (a) was deposited in the Cambridge Structure Database (CSD) as CCDC 1866668.

Figure 3 shows the Raman spectra in the spectral range corresponding to the $\mathrm{SO}_{2}$ scissoring vibration of SL. ${ }^{30}$ This peak appears at $568 \mathrm{~cm}^{-1}$ in neat SL, and shifts to higher wavenumber upon complexation with $\mathrm{Li}^{+}$. As shown in Figure 3, the crystals of $\mathrm{LiBF}_{4}: \mathrm{SL}=1: 1$ showed a relatively sharp peak at $576 \mathrm{~cm}^{-1}$ while $\mathrm{LiClO}_{4}: \mathrm{SL}=1: 2$ exhibited two peaks at 571 and $580 \mathrm{~cm}^{-1}$. Taking into account both the crystal structures and Raman spectra, the $\mathrm{SO}_{2}$ vibration observed at $576 \mathrm{~cm}^{-1}$ for the solid state $\mathrm{LiBF}_{4}: \mathrm{SL}=1: 1$ is assigned to the sulfone group coordinating to different $\mathrm{Li}^{+}$ions (i.e. bridging type SL). The two peaks at 571 and $580 \mathrm{~cm}^{-1}$ for the $\mathrm{LiClO}_{4}: \mathrm{SL}=1: 2$ crystal correspond to the two types of SL, i.e., monodentate and bridging types, in the crystal. Specifically, the higher wavenumber peak $\left(580 \mathrm{~cm}^{-1}\right)$ was attributed to the bridging type SL, and the lower wavenumber peak $\left(571 \mathrm{~cm}^{-1}\right)$ was attributed to the $\mathrm{SL}$ coordinated to only one $\mathrm{Li}^{+}$ion as a monodentate ligand (Figure 2). As shown in Figure 3, the peaks corresponding to the $\mathrm{SO}_{2}$ scissoring vibration for $\mathrm{LiBF}_{4}: \mathrm{SL}=1: 1$ and $\mathrm{LiClO}_{4}: \mathrm{SL}=1: 2$ were broadened upon melting, indicating that the solvation structures change dynamically in the liquids. In the spectrum for $\mathrm{LiClO}_{4}: \mathrm{SL}=1: 2$ in the liquid state, the two peaks 
at 571 and $580 \mathrm{~cm}^{-1}$ overlapped significantly, and the peak area of $571 \mathrm{~cm}^{-1}$ became larger than that of $580 \mathrm{~cm}^{-1}$ (Figure S9), suggesting that the proportion of monodentate SL increased with melting (Table S7). In addition, the tailing of the peak to lower wavenumber $\sim 560 \mathrm{~cm}^{-1}$ indicates that free SL, which is not bound to $\mathrm{Li}^{+}$, was generated upon melting. In the case of $\mathrm{LiBF}_{4}: \mathrm{SL}=1: 1$, the $\mathrm{SO}_{2}$ peak shifted slightly to lower wavenumber upon melting (Figure 3). This implies that some portion of the bridging type SL changed to the monodentate type; however, a significant amount of bridging type SL was still present. The Raman spectrum of $\mathrm{LiBF}_{4}: \mathrm{SL}=1: 2$ solution also exhibits a broadened peak in the range $565 \sim 590 \mathrm{~cm}^{-1}$. It is thus clear that a certain proportion of SL behaves as a bridging ligand in addition to monodentate coordination, in the liquid (Figure S10, Table S8). We note here that the fitting results shown in Figures S9, S10 and Tables S7, S8 can only provide an approximation of the relative proportions of the various coordination types. 

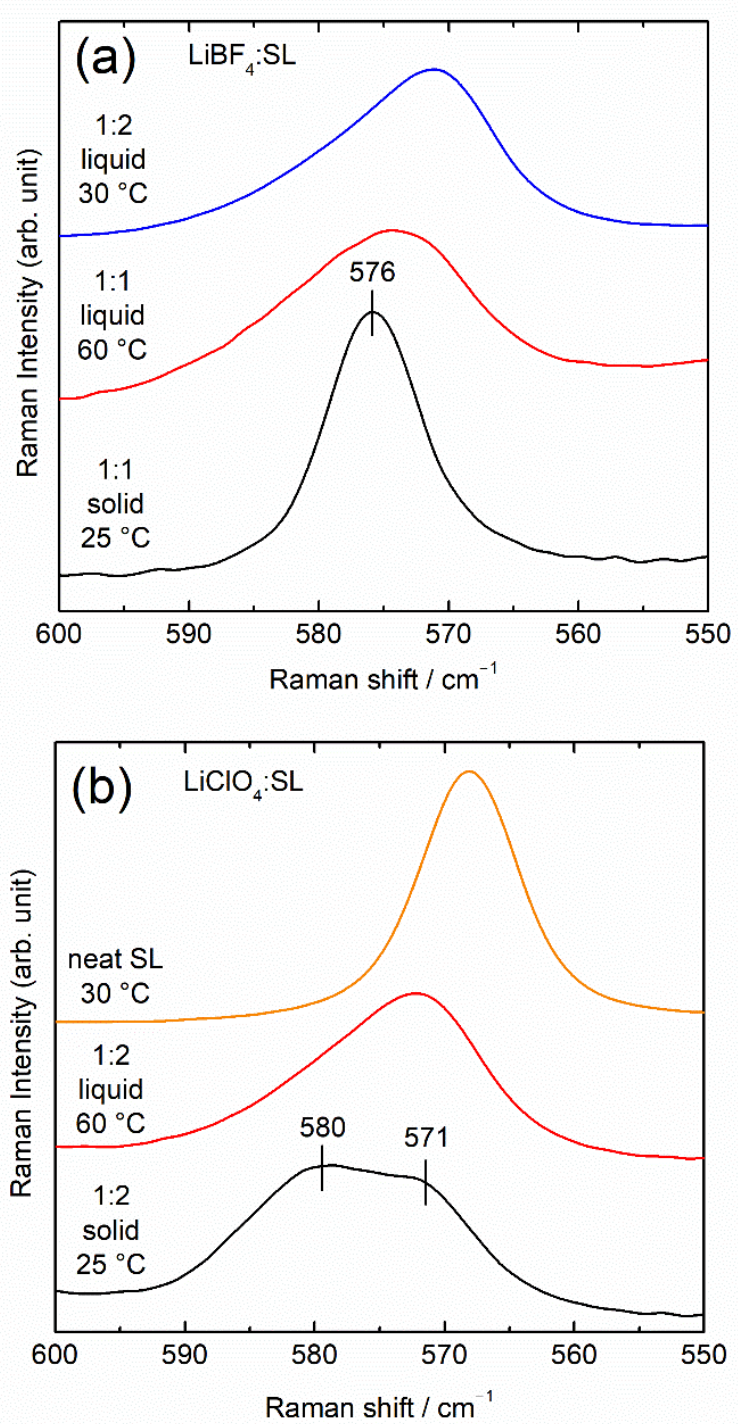

Figure 3. Raman spectra in the region of the scissoring mode of $\mathrm{SO}_{2}$ group of $\mathrm{SL}$ in $\mathrm{LiBF}_{4}$ SL (a) and $\mathrm{LiClO}_{4}-\mathrm{SL}(\mathrm{b})$.

Similarly, the characteristic Raman bands for the anions provide information regarding the interaction between $\mathrm{Li}^{+}$and the anions in the Li salt-SL electrolytes. The Raman spectrum of the $\mathrm{LiBF}_{4}: \mathrm{SL}=1: 1$ solvate (crystal) is shown in Figure 4a. The band observed at $775 \mathrm{~cm}^{-1}$, which is the $\mathrm{B}-\mathrm{F}$ symmetric stretching mode, is assigned to the specific coordination and geometry of $\mathrm{BF}_{4}^{-}$in the aggregated structure, where two fluorine atoms of a $\mathrm{BF}_{4}^{-}$anion are involved in the coordination of different $\mathrm{Li}^{+}$ions, i.e. $\mathrm{BF}_{4}^{-}$anion bridges $\mathrm{Li}^{+}$ions (Figure $\mathbf{2 a}$ ). Upon melting, the $\mathrm{BF}_{4}^{-}$peak becomes broader, suggesting that the aggregated structure of Li- 
$\mathrm{BF}_{4}$ changed. We also note here the melting of the crystal itself would be expected to contribute to the observed broadening, the shift of the peak maximum also suggests changes in the coordination structures. According to Henderson et al., the Raman band of $\mathrm{BF}_{4}{ }^{-}$anion changes depending on the number of $\mathrm{Li}^{+}$ions bound to a single $\mathrm{BF}_{4}{ }^{-}$anion. ${ }^{31}$ Specifically, free or solvent separated ion pair (SSIP) type $\mathrm{BF}_{4}^{-}$anion exhibits a peak in the range $764-765 \mathrm{~cm}^{-1}$, and $\mathrm{BF}_{4}^{-}$forming a contact ion pair (CIP) bound to only one $\mathrm{Li}^{+}$shows a peak at $767 \mathrm{~cm}^{-1}$. In addition, $\mathrm{BF}_{4}^{-}$bound to two $\mathrm{Li}^{+}$ions (AGG-I type $\mathrm{BF}_{4}^{-}$) shows a band at $\sim 777-779 \mathrm{~cm}^{-1}$, and the band of $\mathrm{BF}_{4}^{-}$bound to three $\mathrm{Li}^{+}$ions (AGG-II type $\mathrm{BF}_{4}^{-}$) locates over a wide range of $\sim 776-788 \mathrm{~cm}^{-1}$. Therefore, the broadening of the anionic peak by melting suggests that some portion of the AGG-I type $\mathrm{BF}_{4}^{-}$observed in the crystal was transformed into AGG-II type. This is because the population of bridging type $\mathrm{SL}$ decreases with melting of $\mathrm{LiBF}_{4}: \mathrm{SL}=1: 1$ (vide supra), and thus $\mathrm{BF}_{4}^{-}$anions should be involved in the coordination of more than two $\mathrm{Li}^{+}$ions to satisfy the preferred coordination number of $\mathrm{Li}^{+}$. Similar to the case of $\mathrm{LiBF}_{4}: \mathrm{SL}=1: 1$, the solvation structure of $\mathrm{LiClO}_{4}: \mathrm{SL}=1: 2$ changed upon melting. As shown in Figure S11, the Raman peak of $\mathrm{ClO}_{4}^{-}$observed for the $\mathrm{LiClO}_{4}: \mathrm{SL}=1: 2$ crystal at $934 \mathrm{~cm}^{-1}$, which is assigned to the $\mathrm{Cl}-\mathrm{O}$ symmetric stretching mode of $\mathrm{ClO}_{4}^{-}$, shifted to higher wavenumber upon melting. In the crystal of $\mathrm{LiClO}_{4}: \mathrm{SL}=1: 2, \mathrm{ClO}_{4}^{-}$is bound to only one $\mathrm{Li}^{+}$i.e. monodentate. The shift of $\mathrm{ClO}_{4}^{-}$peak to higher wavenumber suggests that a $\mathrm{ClO}_{4}{ }^{-}$binds to more than one $\mathrm{Li}^{+}$ion in the liquid. ${ }^{32}$ Again, this is because the population of bridging type SL decreases upon melting of $\mathrm{LiClO}_{4}: \mathrm{SL}=1: 2$ (vide supra).

Figure $4 \mathbf{b}$ shows the Raman spectra in the range of $720-820 \mathrm{~cm}^{-1}$ for $\mathrm{LiBF}_{4}-\mathrm{SL}$ mixed at various molar ratios. The Raman band for the symmetric vibration of $\mathrm{BF}_{4}^{-}$is observed at $766 \mathrm{~cm}^{-1}$ for $\mathrm{LiBF}_{4}: \mathrm{SL}=1: 10$ (i.e. $1.0 \mathrm{~mol} \mathrm{dm}^{-3} \mathrm{LiBF}_{4}-\mathrm{SL}$, see Table S1). For the concentrated solutions, $\mathrm{LiBF}_{4}: \mathrm{SL}=1: 3$ and 1:2, the peak showed a shoulder and the peak at $775 \mathrm{~cm}^{-1}$ become prominent, although the band corresponding to the $\mathrm{CH}_{2}$ rocking mode of SL at $788 \mathrm{~cm}^{-1}$ 
overlaps. As previously mentioned, the Raman band of $\mathrm{BF}_{4}^{-}$is sensitive to the formation of aggregated structures of $\mathrm{Li}^{+}$and $\mathrm{BF}_{4}^{-}$. The intense peak observed at $775 \mathrm{~cm}^{-1}$ indicates the formation of AGGs in the liquid electrolytes. Consequently, it was revealed that a significant proportion of AGGs, where $\mathrm{BF}_{4}^{-}$is bound to two or more $\mathrm{Li}^{+}$ions, are formed in the liquids with bulk compositions of $\mathrm{SL} / \mathrm{LiBF}_{4} \leq 3$.
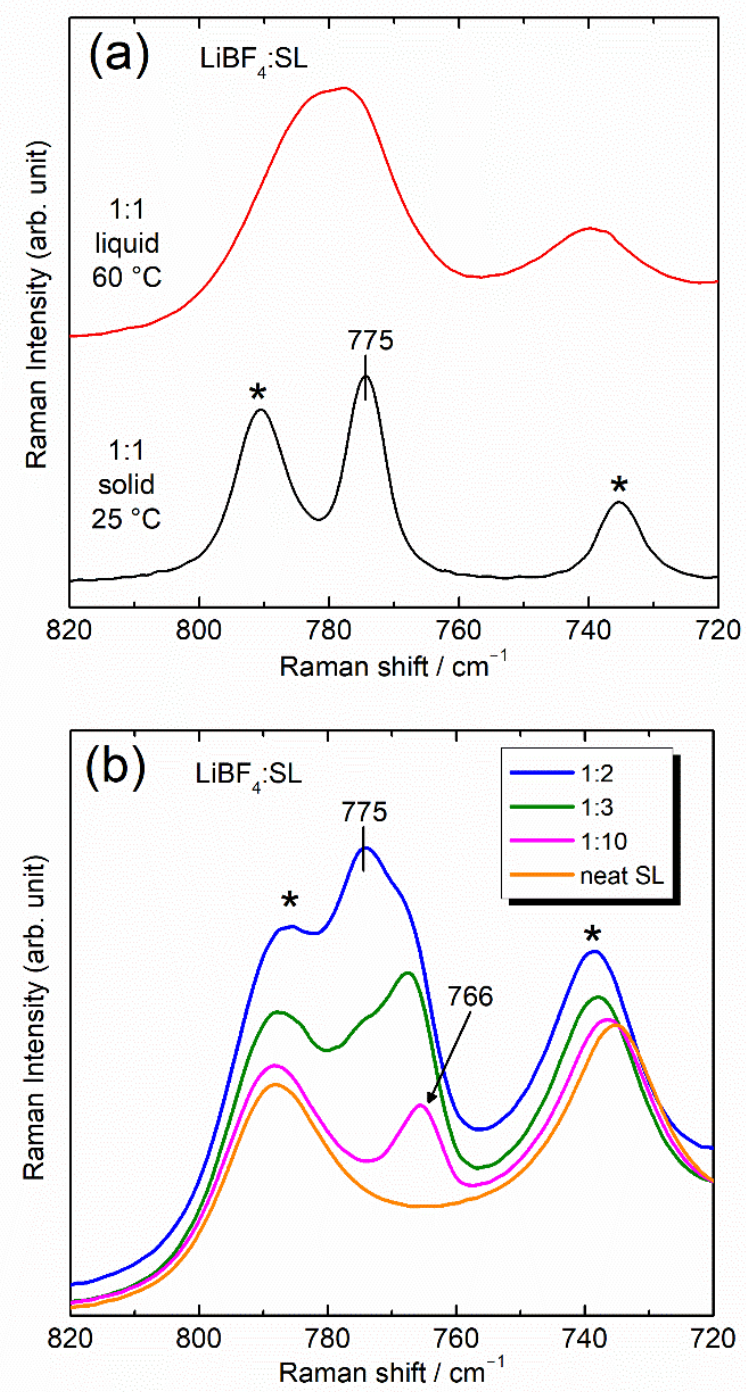

Figure 4. Raman spectra of $\mathrm{BF}_{4}^{-}$in the $\mathrm{LiBF}_{4}: \mathrm{SL}=1: 1$ (a), and $\mathrm{LiBF}_{4}-\mathrm{SL}$ binary mixtures with various molar ratios $\left(\mathrm{LiBF}_{4}: \mathrm{SL}=1: x\right)\left(\right.$ b). The peaks $\left({ }^{*}\right)$ at 735 and $790 \mathrm{~cm}^{-1}$ are the CS-C antisymmetric stretching and $\mathrm{CH}_{2}$ rocking vibration modes of SL, respectively. ${ }^{30}$

$\mathbf{L i}^{+}$hopping conduction mechanism. The fact that $D_{\mathrm{Li}}$ is larger than $D_{\mathrm{SL}}$ and $D_{\mathrm{BF} 4}$ in the $\mathrm{SL} / \mathrm{LiBF}_{4} \leq 3$ electrolytes (Figure 1) strongly suggests that $\mathrm{Li}^{+}$exchanges between the 
coordination sites formed by the ligands $\left(\mathrm{SL}_{\text {and }} \mathrm{BF}_{4}^{-}\right.$) and moves forward leaving behind the ligands. In other words, $\mathrm{Li}^{+}$hopping conduction occurs in the liquids. Note that the hopping conduction is observed in the highly concentrated SL-based electrolytes containing other Li salts, such as $\mathrm{LiClO}_{4}$ and $\mathrm{Li}[\mathrm{FSA}]$ (Figures S1 and S2). The proton hopping conduction mechanism (Grotthuss mechanism) in acidic and basic aqueous solution is well known; however, the hopping conduction of metal ions in liquids has not been well recognized so far. To date, it is known that hopping conduction of $\mathrm{Li}^{+}$occurs in solid electrolytes such as inorganic solid electrolytes and polymer electrolytes. In the $\mathrm{Li}^{+}$ion conducting inorganic solid electrolytes, the positions of ligands, such as oxide ions and sulfide ions, are fixed; however, the coordination sites are closely placed, and $\mathrm{Li}^{+}$ion can hop from one coordination site to the nearest vacant site. ${ }^{33-34}$ In polymer electrolytes, the segmental motion of the polymer chain induces the ligand exchange of $\mathrm{Li}^{+}$, and the $\mathrm{Li}^{+}$hopping conduction takes place. ${ }^{33}$ Another mechanism, concentration-dependent percolation-type diffusion of ions, was also proposed for polymer-in-salt type electrolytes. ${ }^{35-36}$ Regarding the transport properties of aprotic liquid electrolytes, several groups proposed a Grotthuss-type (hopping-type) conduction mechanism of alkali metal ions in electrolytes containing high concentrations of alkali metal salts. ${ }^{12,37-41}$ They reported that the transference number of alkali metal ion $\left(\mathrm{A}^{+}\right)$was increased with increasing salt concentration in the liquid electrolytes. In the highly concentrated electrolytes, the formation of aggregated structures, such as $\left[\mathrm{A}_{x}(\text { solvent })_{\mathrm{y}}(\text { anion })_{z}\right]^{x-z}($ where $x=1$ or more) occurred, and the increase in the transference number of $\mathrm{A}^{+}$was speculated to be due to the ligand exchange of $\mathrm{A}^{+}$in the aggregated structures. MD simulation studies supported the postulation that ligand exchange of the alkali metal ion in the highly concentrated electrolytes contributes to the transport. ${ }^{22,38-40}$

Our present experimental data, the higher diffusion coefficient of $\mathrm{Li}^{+}$than that of $\mathrm{SL}$ and anions (Figure 1, Figures S2 and S3), provides direct evidence that $\mathrm{Li}^{+}$hopping 
conduction occurs in the highly concentrated SL-based electrolytes with molar ratios of SL/Li salt $\leq 3$. In the case of highly concentrated Li salt-SL solution, the viscosity is rather high, and this compels the SL and anions to transport considerably slowly. In addition, both of the two oxygen atoms of the $\mathrm{SL}\left(\mathrm{SO}_{2}\right.$ group) can contribute to the coordination of $\mathrm{Li}^{+}$ions as revealed by X-ray crystallography (Figure 2) and Raman spectroscopy (Figure 3). These provide closely placed coordination sites for $\mathrm{Li}^{+}$ions. Furthermore, the high concentration of anion in the electrolyte can also provide a vast number of coordination sites. These factors are considered to cooperatively promote the $\mathrm{Li}^{+}$hopping conduction and increase the $t_{\mathrm{Li}+}$ in highly concentrated SL-based electrolytes. Here we also note that MD simulations supported our experimental findings i.e. that the ligand exchange and $\mathrm{Li}^{+}$hopping conduction occur in the highly concentrated electrolytes (Figures S12-S17 and Tables S9-S12, Supporting Information). MD simulation reproduced the higher diffusion coefficient of $\mathrm{Li}^{+}$than those of $\mathrm{SL}$ and $\mathrm{BF}_{4}^{-}$in the highly concentrated $\mathrm{LiBF}_{4}-\mathrm{SL}$ electrolytes. $\mathrm{Li}^{+}$ions are dispersed in $\mathrm{SL}$ when the concentration of $\mathrm{LiBF}_{4}$ salt is low $\left(\mathrm{LiBF}_{4}: \mathrm{SL}=1: 8\right)$ as shown in Figure $\mathbf{S 1 7}(\mathbf{a})$ (Supporting Information). On the other hand, $\mathrm{Li}^{+}$ions, $\mathrm{BF}_{4}^{-}$anions and $\mathrm{SO}_{2}$ groups of $\mathrm{SL}$ molecules form aggregates (polar domain) and the methylene groups of SL molecules form aggregates (nonpolar domain) in the mixture when the concentration of $\mathrm{LiBF}_{4}$ salt is high $\left(\mathrm{LiBF}_{4}: \mathrm{SL}=1: 2\right)$ as shown in Figure S17(b) (Supporting Information), which suggests that nano-phase separation occurs in the mixture at high $\mathrm{LiBF}_{4}$ concentrations. The concentration dependence of the liquid structure of the mixture suggests that the formation of the polar domain plays an important role in the evolution of $\mathrm{Li}^{+}$hopping conduction.

Electrochemical properties. To further investigate the $\mathrm{Li}^{+}$ion transport in the SLbased electrolytes, electrochemical measurements were carried out. Cyclic voltammetry was initially performed, demonstrating that the lithium deposition/dissolution processes are both observed in a concentrated $\mathrm{LiBF}_{4}-\mathrm{SL}$ electrolyte (Figure S18). We note here that efficient 
cycling of a lithium metal anode in a concentrated $\mathrm{Li}[\mathrm{FSA}]-\mathrm{SL}$ mixture was recently reported. ${ }^{23}$ Chronoamperometry (CA) was performed in symmetric cells i.e. [Li metal | electrolyte | Li metal], where-in the negative and positive electrodes were separated with 4 sheets of porous polyolefin film (Celgard 3501), and the distance between the electrodes was $100 \mu \mathrm{m}$. Figure 5a shows the current responses of the cell with $\mathrm{LiBF}_{4}: \mathrm{SL}=1: 10$ electrolyte measured at various applied voltages. Upon increasing the voltage, the current increases owing to the increase in the charge transfer rate at the Li metal electrodes. The current decayed with time up to $200 \mathrm{~s}$ after voltage application, and a steady state current was observed after 200 s. During the CA measurements, electrodeposition and dissolution of $\mathrm{Li}$ metal occur at the negative and positive electrodes, respectively, while the anion, $\mathrm{BF}_{4}^{-}$, cannot be discharged at the electrodes. The $t_{\mathrm{Li}+}$ is less than 1 in liquid electrolytes, and this causes the concentration polarization of $\mathrm{LiBF}_{4}$ in the cell. ${ }^{42}$ Through electrochemical reactions at the negative and positive electrodes, a concentration gradient of $\mathrm{LiBF}_{4}$ is formed in the vicinity of the electrodes. The growth of the diffusion layer from the negative electrode to positive electrode, across the electrolyte, completed within $200 \mathrm{~s}$ and reached the steady state. The steady state current increased with increasing the applied voltage up to $400 \mathrm{mV}$, however, became constant $\left(2.5 \mathrm{~mA} \mathrm{~cm}{ }^{-2}\right)$ and independent of the voltage at higher than $450 \mathrm{mV}$, suggesting that the Faradaic current reached the $\mathrm{Li}^{+}$-diffusion limiting current density. Under the diffusion limiting condition, it is assumed that the depletion of $\mathrm{LiBF}_{4}$ occurs at the negative Li metal electrode, and the limiting current density can be roughly calculated, based on the diffusion coefficient of $\mathrm{Li}^{+}$, to be $1.5 \mathrm{~mA} \mathrm{~cm}{ }^{-2}$ (Table S13, Supporting Information), which similar in magnitude to the experimentally observed value $\left(2.5 \mathrm{~mA} \mathrm{~cm}^{-2}\right)$. In this way, concentration polarization occurs at high current density in the electrolyte containing excess $\mathrm{SL}\left(\mathrm{LiBF}_{4}: \mathrm{SL}=1: 10\right)$, and the maximum electrochemical reaction rate is limited by the chemical diffusion of $\mathrm{Li}^{+}$.

To investigate the effect of $\mathrm{Li}^{+}$hopping conduction on the electrochemical reaction rate, 
analogous $\mathrm{CA}$ measurements were carried out for a $\mathrm{Li} / \mathrm{Li}$ symmetric cell with $\mathrm{LiBF}_{4}: \mathrm{SL}=1: 2$ (Figure 5b). At each voltage, the Faradaic current is observed from the moment the voltage is applied to the cell, and the current is more or less constant and time independent. This behavior is in stark contrast to that of the cell with $\mathrm{LiBF}_{4}: \mathrm{SL}=1: 10$ (Figure 5a). The time independent current suggests that the growth of the concentration polarization in the $\mathrm{LiBF}_{4}: \mathrm{SL}=1: 2$ electrolyte was not so remarkable after the start of electrolysis, regardless of the production and consumption of $\mathrm{Li}^{+}$at the positive and negative electrodes, respectively. In other words, the chemical diffusion of $\mathrm{Li}^{+}$(i.e. due to concentration gradient) in the electrolyte makes less contribution to the current, and the concentration polarization was greatly suppressed. This is likely because the $\mathrm{Li}^{+}$ion migration through hopping conduction makes a larger contribution to the current than that of the chemical diffusion. We note here that a slight increase of current with time was observed for the concentrated electrolyte (Figure 5b). This slight increase of the current might be due to the decrease of the interfacial resistance at the initial stage of the electrolysis. The electrodeposition and dissolution of Li metal would cause the roughening of the electrodes. The roughening of the electrode surface increases the surface area of the electrodes, leading to the decrease of charge transfer resistance for the electrochemical reaction and the increase of the migration current in the electrolyte solution. When $\mathrm{Li}^{+}$hopping transport occurs in the electrolyte, the $t_{\mathrm{Li}+}$ becomes larger, and the contribution of the anion to the charge transport becomes smaller. Strikingly, the $D_{\mathrm{BF}} / D_{\mathrm{Li}}$ decreases with increasing $\mathrm{LiBF}_{4}$ concentration in the electrolytes (Figure 1c), indicating that the $t_{\mathrm{Li}+}$ increases with $\mathrm{LiBF}_{4}$ concentration. In addition, the $t_{\mathrm{Li}+}$ estimated by an electrochemical method also showed the same concentration-dependent trend (Figure S19, Table S14). The higher $t_{\mathrm{Li}+}$ results in a gentle slope of Li salt concentration gradient in the electrolyte during the electrolysis. ${ }^{42-43}$ The extreme case of this situation is a typical inorganic $\mathrm{Li}^{+}$ion conductor, in which the position of anion is fixed and $t_{\mathrm{Li+}}=1$, and the concentration gradient of $\mathrm{Li}^{+}$ion is hardly formed. In the 
case of migration-controlled $\mathrm{Li}^{+}$transport, the current should increase with increasing applied voltage. Indeed, the steady state current for the symmetric cell with $\mathrm{LiBF}_{4}: \mathrm{SL}=1: 2$ electrolyte continuously increased with increasing applied voltage, and the steady-state current observed for the cell at $700 \mathrm{mV}$ was as high as $3.5 \mathrm{~mA} \mathrm{~cm}^{-2}$. Note that the ionic conductivity of $\mathrm{LiBF}_{4}: \mathrm{SL}$ $=1: 2$ is $0.61 \mathrm{mS} \mathrm{cm}^{-1}$, notably lower than that of $\mathrm{LiBF}_{4}: \mathrm{SL}=1: 10\left(1.63 \mathrm{mS} \mathrm{cm}^{-1}\right)$; nevertheless a higher current density can be achieved in $\mathrm{LiBF}_{4}: \mathrm{SL}=1: 2$ (Figure 5c). We note here that the dendritic growth of Li metal occurs at the negative electrode with a polarization higher than $700 \mathrm{mV}$. This resulted in the internal short circuit of the cell, and unfortunately reproducible data could not be obtained at higher than $700 \mathrm{mV}$. 



Figure 5. Chronoamperograms for symmetric $\left[\mathrm{Li} \mid \mathrm{LiBF}_{4}-\mathrm{SL}\right.$ with 4 sheets of Celgard 3501 $(100 \mu \mathrm{m}) \mid \mathrm{Li}]$ cells measured at various applied voltages at $30^{\circ} \mathrm{C}$. The electrolyte compositions were with $\mathrm{LiBF}_{4}: \mathrm{SL}=1: 10$ (a) and 1:2 (b). Dependences of steady state current densities of the symmetric cells on the applied voltage (c).

Finally, we examined the effects of the $\mathrm{Li}^{+}$ion transport properties of the electrolytes on Li battery performance. Figure 6 shows the discharge rate capabilities of $\mathrm{Li} / \mathrm{LiCoO}_{2}$ cells with $\mathrm{LiBF}_{4}: \mathrm{SL}=1: 2$ and 1:10 electrolytes. The discharge curves measured at various current densities are shown in Figure S20. At low current densities, both cells showed a discharge capacity of ca. $140 \mathrm{mAh} \mathrm{g}^{-1}$, which is close to the theoretical capacity of $\mathrm{LiCoO}_{2}$. With 
increasing current density, the discharge capacities of the cells decreased owing to the $\mathrm{Li}^{+}$ transport limitation in the electrolytes. The discharge capacity of the cell with $\mathrm{LiBF}_{4}: \mathrm{SL}=1: 10$ was as low as $20 \mathrm{mAh} \mathrm{g}^{-1}$ at $2.65 \mathrm{~mA} \mathrm{~cm}^{-2}$. This is because the current density is close to the limiting current of $\mathrm{LiBF}_{4}: \mathrm{SL}=1: 10$. On the other hand, the cell with $\mathrm{LiBF}_{4}: \mathrm{SL}=1: 2$ showed a capacity of $80 \mathrm{mAh} \mathrm{g}^{-1}$ at $2.65 \mathrm{~mA} \mathrm{~cm} \mathrm{~cm}^{-2}$. The superior rate capability of the cell with $\mathrm{LiBF}_{4}: \mathrm{SL}=1: 2$ electrolyte is ascribed to the higher limiting current and the suppressed concentration polarization. The ionic conductivity of the $\mathrm{LiBF}_{4}: \mathrm{SL}=1: 2$ is not so high at room temperature owing to its high viscosity. However, with increasing the temperature, the viscosity of the liquid decreases and the ionic conductivity increases (Figure S21 and Table S15, Supporting Information). Even at the elevated temperature $\left(\sim 90{ }^{\circ} \mathrm{C}\right), \mathrm{Li}^{+}$diffuses faster than $\mathrm{BF}_{4}^{-}$and SL, i.e., the hopping conduction of $\mathrm{Li}^{+}$occurs (Figure S22). In addition, with increasing the temperature, the higher limiting current density in an electrochemical cell can be achieved (Figure S23). This may be instrumental to further improve the power density of lithium batteries.

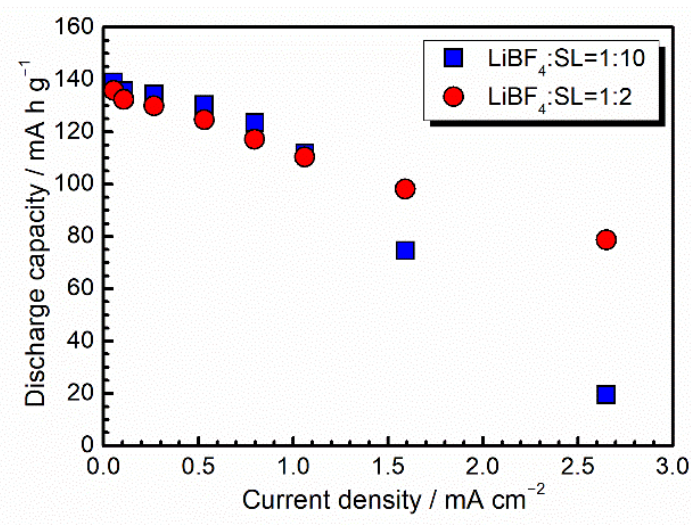

Figure 6. Discharge capacities of $\left[\mathrm{Li} \mid \mathrm{LiBF}_{4}-\mathrm{SL}\right.$ with 2 sheets of Celgard $3501(50 \mu \mathrm{m}) \mid$ $\mathrm{LiCoO}_{2}$ ] cells measured at various current densities at $30^{\circ} \mathrm{C}$. The cells were fully charged prior to each discharge measurement at a low current density of $53 \mu \mathrm{A} \mathrm{cm}^{-2}$.

\section{Conclusions}

In this study, we elucidated the liquid structures and transport properties of highly 
concentrated $\mathrm{LiBF}_{4}-\mathrm{SL}$ electrolytes. In the electrolytes with compositions of SL/LiBF $4 \leq 3, \mathrm{Li}^{+}$ diffuses faster than both the SL solvent and $\mathrm{BF}_{4}^{-}$anion. We demonstrated that the $\mathrm{Li}^{+}$hopping conduction through ligand exchange occurs in the highly concentrated electrolytes. Both SL and $\mathrm{BF}_{4}{ }^{-}$anion function as ligands for $\mathrm{Li}^{+}$ions. The oxygen atoms of the sulfone moiety $\left(\mathrm{SO}_{2}\right)$ of a SL molecule coordinate to different $\mathrm{Li}^{+}$ions and bridge them. In addition, the $\mathrm{BF}_{4}{ }^{-}$anions also bridge different $\mathrm{Li}^{+}$ions. The $\mathrm{SL}$ and $\mathrm{BF}_{4}{ }^{-}$provide closely placed coordination sites in the highly concentrated electrolytes. $\mathrm{Li}^{+}$ion hops from one coordination site to another with ligand exchange in the liquid. In addition, we found that $\mathrm{Li}^{+}$hopping conduction occurs in the highly concentrated SL-based electrolytes containing other $\mathrm{Li}$ salts, such as $\mathrm{LiClO}_{4}$ and $\mathrm{Li}[\mathrm{FSA}]$. The $\mathrm{Li}^{+}$hopping conduction was effective in suppressing the concentration polarization in a lithium battery. Identification and rationalization of $\mathrm{Li}^{+}$ion hopping in the concentrated SL electrolytes is expected to trigger a new paradigm of understanding for such unconventional electrolyte systems.

\section{EXPERIMENTAL SECTION}

Purified SL, $\mathrm{LiBF}_{4}, \mathrm{LiClO}_{4}$, and $\mathrm{Li}[\mathrm{FSA}]$ were purchased from Kishida Chemical and used as received. SL and $\mathrm{Li}$ salts were mixed in a glove box filled with argon gas $\left(\mathrm{VAC},\left[\mathrm{H}_{2} \mathrm{O}\right]\right.$ $<1 \mathrm{ppm})$. The mixtures were stirred for $24 \mathrm{~h}$ at room temperature, and homogeneous liquids were obtained. The detailed compositions of the electrolytes are shown in Tables S1-S3 (Supporting Information). The liquids were stored and handled in the glove box. The ionic conductivities $(\sigma)$ of electrolytes were determined by the complex impedance method using an impedance analyzer (VMP3, Biologic) in the frequency range of $500 \mathrm{kHz}-1 \mathrm{~Hz}$ with a sinusoidal alternating voltage amplitude of $10 \mathrm{mV}$ root-mean-square (rms). A cell equipped with two platinized platinum electrodes (CG-511B, TOA Electronics) was utilized for the conductivity measurements, and the cell constant was determined using a $0.01 \mathrm{M} \mathrm{KCl}$ aqueous 
solution at $25{ }^{\circ} \mathrm{C}$ prior to the measurements. The cell was placed in a temperature-controlled chamber and conductivity was measured at $30{ }^{\circ} \mathrm{C}$. The liquid density and viscosity were determined using a viscometer (SVM 3000, Anton Paar).

PFG-NMR measurements were carried out to determine the self-diffusion coefficients of the SL, $\mathrm{Li}^{+}$, and $\mathrm{BF}_{4}^{-}$in the electrolytes. A JEOL-ECX 400 NMR spectrometer with a $9.4 \mathrm{~T}$ narrow-bore super-conducting magnet equipped with a pulsed-field gradient probe and current amplifier was used for these measurements. Self-diffusion coefficients were calculated with the Hahn spin-echo sequence using the ${ }^{1} \mathrm{H}$ signals of $\mathrm{SL},{ }^{7} \mathrm{Li}$ signal of $\mathrm{Li}^{+}$, and the ${ }^{19} \mathrm{~F}$ signal of $\mathrm{BF}_{4}^{-}$. The detailed experimental procedures have been reported elsewhere. ${ }^{44}$ The diffusion echo signal attenuation, $E$, is related to the experimental parameters by the Stejskal equation ${ }^{45}$ with a sinusoidal pulsed-field gradient:

$$
\ln (E)=\ln \left(S / S_{\delta=0}\right)=\frac{-\gamma^{2} \mathrm{~g}^{2} D \delta^{2}(4 \Delta-\delta)}{\pi^{2}}
$$

where $S$ is the spin-echo signal intensity, $\delta$ is the duration of the field gradient with magnitude $g, \gamma$ is the gyromagnetic ratio, and $\Delta$ is the interval between the two gradient pulses. The values of $\Delta$ and $\delta$ were set to $50 \mathrm{~ms}$ and $5 \mathrm{~ms}$, respectively, whereas $g$ was set to $0.01 \sim 1.9 \mathrm{~T} \mathrm{~m}^{-1}$ depending on the electrolyte. The sample was inserted into an NMR microtube to a height of 3 $\mathrm{mm}$ to exclude convection. All measurements were conducted at $30{ }^{\circ} \mathrm{C}$. Each sample was placed in a sample tube with an outer diameter of $4 \mathrm{~mm}$, and that tube was inserted into a 5 mm standard NMR sample tube.

The thermal properties of the binary mixtures of Li salts and SL were evaluated by differential scanning calorimetry (DSC) using a DSC6220 (Seiko). The samples for DSC were sealed in aluminum pans in the glovebox. The sample pans were first heated to appropriately high temperatures to avoid thermal hysteresis, followed by cooling to $-150{ }^{\circ} \mathrm{C}$ and finally heating to $100{ }^{\circ} \mathrm{C}$ at a rate of $5{ }^{\circ} \mathrm{C} \mathrm{min}^{-1}$. The thermograms in the final heating process were analyzed. The $T_{\mathrm{m}}$ and glass transition temperature $\left(T_{\mathrm{g}}\right)$ were estimated from the maxima of the 
endothermic peaks and the onsets of the changes in heat capacities, respectively.

Single crystal X-ray structure analysis was performed on a Rigaku Mercury70 or XtaLab P2000 diffractometer using monochromatic Mo K $\alpha$ radiation $(\lambda=0.71073 \AA$ A). Single crystals of the solvates $\mathrm{LiBF}_{4}: \mathrm{SL}=1: 1, \mathrm{LiClO}_{4}: \mathrm{SL}=1: 2$, and $\mathrm{Li}[\mathrm{FSA}]: \mathrm{SL}=1: 1$ were successfully grown in the liquids of binary mixtures of $\mathrm{LiBF}_{4}: \mathrm{SL}=1: 1, \mathrm{LiClO}_{4}: \mathrm{SL}=1: 2.5$, and $\mathrm{Li}[\mathrm{FSA}]: \mathrm{SL}$ $=1: 1.5$, respectively. The single crystals were coated with vacuum grease to prevent contact with air, and mounted on a glass pin. The diffraction was measured at low temperature using a steady flow of $-50{ }^{\circ} \mathrm{C}$ nitrogen gas. An empirical absorption correction was applied to the obtained data using multiscan averaging of symmetry equivalent data using spherical harmonics, implemented in the SCALES3 ABSPACK scaling algorithm (CrysAlisPro 1.171.38.43, Rigaku Oxford Diffraction, 2015). The crystallographic structure was solved by the direct method with SHELXT and all non-hydrogen atoms were refined anisotropically by the full-matrix least-squares method using SHELXL-2014/7.46-47 All hydrogen atoms were placed at geometrically ideal positions and refined using an appropriate riding model. The crystallographic data are summarized in Tables S4-S6. Raman spectra of the electrolytes were collected using a Raman spectrometer equipped with a $532 \mathrm{~nm}$ laser (RMP-330, JASCO). The instrument was calibrated using a polypropylene standard. The spectral resolution was $4.5 \mathrm{~cm}^{-1}$. The sample temperature was controlled using a Peltier microscope stage (TS62, Instec) with a temperature controller (mK1000, Instec).

For the cyclic voltammetry tests, a $[\mathrm{Li}$ foil $\mid$ electrolyte $\mid \mathrm{Cu}$ foil] coin cell was constructed in the glove box, and the voltage was swept from open-circuit voltage to $-0.5 \mathrm{~V}$ vs. $\mathrm{Li} / \mathrm{Li}^{+}$and then reversed to $2.5 \mathrm{~V}$ vs. $\mathrm{Li} / \mathrm{Li}^{+}$, with a scan rate of $5 \mathrm{mV} \mathrm{s}^{-1}$ at $30{ }^{\circ} \mathrm{C}$. For the estimation of limiting current density, symmetrical [Li metal | electrolyte | Li metal] cells were fabricated in the glove box. Li metal foil was purchased from Honjo Metal and cut into a disk shape (16 $\mathrm{mm}$ in diameter). 4 sheets of porous polyolefin film (Celgard 3501, $25 \mu \mathrm{m}$ thick, 
porosity: 55\%) were inserted between the two Li metal electrodes (a relatively large number of separator sheets was required to alleviate lithium dendrite formation during the measurements). The Li metal electrodes and an electrolyte were encapsulated into a 2032-type coin cell in the glove box. The electrolyte permeated into the voids of the polyolefin films during the cell fabrication. The symmetric configuration was encapsulated in a 2032 type coin cell. For Li transference number determination by electrochemical polarization, a similar procedure was followed, with 2 sheets of Celgard rather than 4. For the battery tests, [Li metal anode | electrolyte $\mid \mathrm{LiCoO}_{2}$ cathode] coin cells were constructed, and galvanostatic charge-discharge measurements were carried out. The cathode was composed of $\mathrm{LiCoO}_{2}(80 \mathrm{wt} . \%$, AGC Seimi Chemical) as a cathode-active material, acetylene black (10 wt.\%, Denki Kagaku Kogyo) as an electrically conductive additive, and poly(vinylidene fluoride) (10 wt.\%, Kureha Chemical) as a binder polymer. These materials were mixed together and thoroughly agitated in $\mathrm{N}$ methylpyrrolidone with a homogenizer. The obtained slurry was applied with an automatic applicator onto an $\mathrm{Al}$ foil, and the resulting cathode sheet was dried at $80{ }^{\circ} \mathrm{C}$ for $12 \mathrm{~h}$. Then, the cathode sheet was then cut into a disk (16 mm diameter) and compressed at $50 \mathrm{MPa}$ followed by drying in a vacuum at $120^{\circ} \mathrm{C}$ for $12 \mathrm{~h}$. The thickness of the composite cathode layer on $\mathrm{Al}$ foil was $20 \mu \mathrm{m}$, and the loading of $\mathrm{LiCoO}_{2}$ was approximately $4 \mathrm{mg} \mathrm{cm}^{-2}$. The cathode sheet, 2 sheets of Celgard 3501, Li salt-SL electrolyte, and a Li metal anode were encapsulated into a 2032-type coin cell in the glove box. Galvanostatic charge-discharge tests were carried out using an automatic charge/discharge instrument (HJ1001SD8, Hokuto Denko) in the voltage range of $3.0-4.2 \mathrm{~V}$ at $30^{\circ} \mathrm{C}$.

\section{ASSOCIATED CONTENT}

\section{Supporting Information.}


This material is available free of charge via the Internet at http://pubs.acs.org.

Tables S1-S15, Figure S1-S23, and MD simulation details (PDF)

Crystallographic information for $\mathrm{LiBF}_{4}: \mathrm{SL}(1: 1)$

Crystallographic information for Li[FSA]:SL (1:1)

Crystallographic information for $\mathrm{LiClO}_{4}$ :SL (1:2)

Full list of authors for references 22, 23 and 34

\author{
AUTHOR INFORMATION \\ Corresponding Author \\ *Telephone/Fax: +81-45-339-3955. E-mail: mwatanab@ynu.ac.jp
}

\title{
Notes
}

The authors declare no conflict of interest.

\section{ACKNOWLEDGEMENTS}

Mr. Kenta Watanabe for his kind help in measuring PFG-NMR. This study was supported in part by the JSPS KAKENHI (Grant Nos. 16H06368 and 18H03926) from the Japan Society for the Promotion of Science (JSPS) and the Advanced Low Carbon Technology Research and Development Program (ALCA) of the Japan Science and Technology Agency (JST). 


\section{References}

1. Bockris, J. O. M.; Reddy, A. K. N., Modern Electrochemistry: Volume 1. 2nd ed; Kluwer Academic/Plenum Publishers: New York, 1998.

2. Izutsu, K., Electrochemistry in Nonaqueous Solutions. 2nd ed.; Wiley-VCH Verlag GmbH \& Co. KGaA: Weinheim, 2009.

3. Robinson, R. A.; Stokes, R. H., Electrolyte solutions. Butterworth \& Co. Ltd.: Washington, DC, 1959.

4. $\mathrm{Xu}, \mathrm{K}$., Nonaqueous Liquid Electrolytes for Lithium-Based Rechargeable Batteries. Chem. Rev. 2004, 104, 4303-4418.

5. $\mathrm{Xu}, \mathrm{K}$. , Electrolytes and Interphases in Li-Ion Batteries and Beyond. Chem. Rev. 2014, $114,11503-11618$.

6. Suo, L.; Hu, Y. S.; Li, H.; Armand, M.; Chen, L., A New Class of Solvent-in-Salt Electrolyte for High-Energy Rechargeable Metallic Lithium Batteries. Nat. Commun. 2013, 4, 1481.

7. Yamada, Y.; Furukawa, K.; Sodeyama, K.; Kikuchi, K.; Yaegashi, M.; Tateyama, Y.; Yamada, A., Unusual Stability of Acetonitrile-Based Superconcentrated Electrolytes for Fast-Charging Lithium-Ion Batteries. J. Am. Chem. Soc. 2014, 136, 5039-5046.

8. Yamada, Y.; Usui, K.; Chiang, C. H.; Kikuchi, K.; Furukawa, K.; Yamada, A., General Observation of Lithium Intercalation into Graphite in Ethylene-Carbonate-Free Superconcentrated Electrolytes. ACS Appl. Mater. Interfaces 2014, 6, 10892-10899.

9. Qian, J.; Henderson, W. A.; Xu, W.; Bhattacharya, P.; Engelhard, M.; Borodin, O.; Zhang, J. G., High Rate and Stable Cycling of Lithium Metal Anode. Nat. Commun. 2015, 6,6362 .

10. Yamada, Y.; Yamada, A., Superconcentrated Electrolytes to Create New Interfacial Chemistry in Non-Aqueous and Aqueous Rechargeable Batteries. Chem. Lett. 2017, 46, 1056-1064.

11. Watanabe, M.; Dokko, K.; Ueno, K.; Thomas, M. L., From Ionic Liquids to Solvate Ionic Liquids: Challenges and Opportunities for Next Generation Battery Electrolytes. Bull. Chem. Soc. Jpn., in press, DOI: 10.1246/bcsj.20180216.

12. Yoshida, K.; Nakamura, M.; Kazue, Y.; Tachikawa, N.; Tsuzuki, S.; Seki, S.; Dokko, K.; Watanabe, M., Oxidative-Stability Enhancement and Charge Transport Mechanism in Glyme-Lithium Salt Equimolar Complexes. J. Am. Chem. Soc. 2011, 133, 1312113129.

13. Yamada, Y.; Yamada, A., Review-Superconcentrated Electrolytes for Lithium Batteries. J. Electrochem. Soc. 2015, 162, A2406-A2423.

14. Wang, J.; Yamada, Y.; Sodeyama, K.; Chiang, C. H.; Tateyama, Y.; Yamada, A., Superconcentrated Electrolytes for a High-Voltage Lithium-Ion Battery. Nat. Commun. 2016, 7, 12032. 
15. $\mathrm{Xu}, \mathrm{K}$. ; Angell, C. A., High Anodic Stability of a New Electrolyte Solvent: Unsymmetric Noncyclic Aliphatic Sulfone. J. Electrochem. Soc. 1998, 145, L70-L72.

16. Xu, K.; Angell, C. A., Sulfone-Based Electrolytes for Lithium-Ion Batteries. J. Electrochem. Soc. 2002, 149, A920-A926.

17. Sun, X.-G.; Angell, C. A., New Sulfone Electrolytes for Rechargeable Lithium Batteries. Electrochem. Commun. 2005, 7, 261-266.

18. Abouimrane, A.; Belharouak, I.; Amine, K., Sulfone-Based Electrolytes for HighVoltage Li-Ion Batteries. Electrochem. Commun. 2009, 11, 1073-1076.

19. Sun, X.; Angell, C. A., Doped Sulfone Electrolytes for High Voltage Li-Ion Cell Applications. Electrochem. Commun. 2009, 11, 1418-1421.

20. Lee, S.-Y.; Ueno, K.; Angell, C. A., Lithium Salt Solutions in Mixed Sulfone and Sulfone-Carbonate Solvents: A Walden Plot Analysis of the Maximally Conductive Compositions. J. Phys. Chem. C 2012, 116, 23915-23920.

21. Xue, L.; Ueno, K.; Lee, S.-Y.; Angell, C. A., Enhanced Performance of Sulfone-Based Electrolytes at Lithium Ion Battery Electrodes, including the $\mathrm{LiNi}_{0.5} \mathrm{Mn}_{1.5} \mathrm{O}_{4}$ High Voltage Cathode. J. Power Sources 2014, 262, 123-128.

22. Alvarado, J.; Schroeder, M. A.; Zhang, M.; Borodin, O.; Gobrogge, E.; Olguin, M.; Ding, M. S.; Gobet, M.; Greenbaum, S.; Meng, Y. S.; et al., A Carbonate-Free, SulfoneBased Electrolyte for High-Voltage Li-Ion Batteries. Mater. Today 2018, 21, 341-353.

23. Ren, X.; Chen, S.; Lee, H.; Mei, D.; Engelhard, M. H.; Burton, S. D.; Zhao, W.; Zheng, J.; Li, Q.; Ding, M. S.; et al., Localized High-Concentration Sulfone Electrolytes for High-Efficiency Lithium-Metal Batteries. Chem 2018, 4, 1877-1892.

24. Hayamizu, K.; Aihara, Y.; Arai, S.; Martinez, C. G., Pulse-Gradient Spin-Echo ${ }^{1}$ H, ${ }^{7}$ Li, and ${ }^{19} \mathrm{~F}$ NMR Diffusion and Ionic Conductivity Measurements of 14 Organic Electrolytes Containing $\mathrm{LiN}\left(\mathrm{SO}_{2} \mathrm{CF}_{3}\right)_{2}$. J. Phys. Chem. B 1999, 103, 519-524.

25. Hayamizu, K.; Akiba, E.; Bando, T.; Aihara, Y., ${ }^{1} \mathrm{H},{ }^{7} \mathrm{Li}$, and ${ }^{19} \mathrm{~F}$ nuclear magnetic resonance and ionic conductivity studies for liquid electrolytes composed of glymes and polyetheneglycol dimethyl ethers of $\mathrm{CH}_{3} \mathrm{O}\left(\mathrm{CH}_{2} \mathrm{CH}_{2} \mathrm{O}\right)_{n} \mathrm{CH}_{3}(\mathrm{n}=3-50)$ doped with $\mathrm{LiN}\left(\mathrm{SO}_{2} \mathrm{CF}_{3}\right)_{2}$. J. Chem. Phys. 2002, 117, 5929-5939.

26. Zhang, C.; Ueno, K.; Yamazaki, A.; Yoshida, K.; Moon, H.; Mandai, T.; Umebayashi, Y.; Dokko, K.; Watanabe, M., Chelate Effects in Glyme/Lithium Bis(trifluoromethanesulfonyl)amide Solvate Ionic Liquids. I. Stability of Solvate Cations and Correlation with Electrolyte Properties. J. Phys. Chem. B 2014, 118, 51445153.

27. Kameda, Y.; Umebayashi, Y.; Takeuchi, M.; Wahab, M. A.; Fukuda, S.; Ishiguro, S.; Sasaki, M.; Amo, Y.; Usuki, T., Solvation Structure of $\mathrm{Li}^{+}$in Concentrated $\mathrm{LiPF}_{6}-$ Propylene Carbonate Solutions. J. Phys. Chem. B 2007, 111, 6104-6109.

28. Roobottom, H. K.; Jenkins, H. D. B.; Passmore, J.; Glasser, L., Thermochemical Radii of Complex Ions. J. Chem. Educ. 1999, 76, 1570-1573. 
29. Ue, M.; Murakami, A.; Nakamura, S., A Convenient Method to Estimate Ion Size for Electrolyte Materials Design. J. Electrochem. Soc. 2002, 149, A1385-A1388.

30. Katon, J. E.; Feairheller, W. R., The Vibrational Spectra and Molecular Configuration of Sulfolane. Spectrochim. Acta 1965, 21, 199-201.

31. Seo, D. M.; Boyle, P. D.; Allen, J. L.; Han, S.-D.; Jónsson, E.; Johansson, P.; Henderson, W. A., Solvate Structures and Computational/Spectroscopic Characterization of $\mathrm{LiBF}_{4}$ Electrolytes. J. Phys. Chem. C 2014, 118, 18377-18386.

32. Chabanel, M.; Legoff, D.; Touaj, K., Aggregation of Perchlorates in Aprotic Donor Solvents. Part 1.-Lithium and Sodium Perchlorates. J. Chem. Soc., Faraday Trans. 1996, 92, 4199-4205.

33. Bruce, P. G., Ed. Solid State Electrochemistry. Cambridge University Press: 1997.

34. Zhang, Z.; Shao, Y.; Lotsch, B.; Hu, Y.-S.; Li, H.; Janek, J.; Nazar, L. F.; Nan, C.-W.; Maier, J.; Armand, M.; et al., New Horizons for Inorganic Solid State Ion Conductors. Energy Environ. Sci. 2018, 11, 1945-1976.

35. Forsyth, M.; Sun, J.; Macfarlane, D. R.; Hill, A. J., Compositional Dependence of Free Volume in $\mathrm{PAN} / \mathrm{LiCF}_{3} \mathrm{SO}_{3}$ Polymer-in-Salt Electrolytes and the Effect on Ionic Conductivity. J. Polym. Sci., Part B: Polym. Phys. 2000, 38, 341-350.

36. Florjańczyk, Z.; Zygadło-Monikowska, E.; Wieczorek, W.; Ryszawy, A.; Tomaszewska, A.; Fredman, K.; Golodnitsky, D.; Peled, E.; Scrosati, B., Polymer-inSalt Electrolytes Based on Acrylonitrile/Butyl Acrylate Copolymers and Lithium Salts. J. Phys. Chem. B 2004, 108, 14907-14914.

37. Brinkkotter, M.; Giffin, G. A.; Moretti, A.; Jeong, S.; Passerini, S.; Schonhoff, M., Relevance of Ion Clusters for Li Transport at Elevated Salt Concentrations in

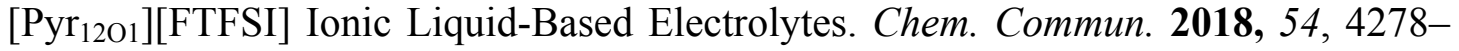
4281.

38. Callsen, M.; Sodeyama, K.; Futera, Z.; Tateyama, Y.; Hamada, I., The Solvation Structure of Lithium Ions in an Ether Based Electrolyte Solution from First-Principles Molecular Dynamics. J. Phys. Chem. B 2017, 121, 180-188.

39. Forsyth, M.; Yoon, H.; Chen, F.; Zhu, H.; MacFarlane, D. R.; Armand, M.; Howlett, P. C., Novel $\mathrm{Na}^{+}$Ion Diffusion Mechanism in Mixed Organic-Inorganic Ionic Liquid Electrolyte Leading to High $\mathrm{Na}^{+}$Transference Number and Stable, High Rate Electrochemical Cycling of Sodium Cells. J. Phys. Chem. C 2016, 120, 4276-4286.

40. Seo, D. M.; Borodin, O.; Balogh, D.; O'Connell, M.; Ly, Q.; Han, S.-D.; Passerini, S.; Henderson, W. A., Electrolyte Solvation and Ionic Association III. AcetonitrileLithium Salt Mixtures-Transport Properties. J. Electrochem. Soc. 2013, 160, A1061A1070.

41. Yim, C.-H.; Tam, J.; Soboleski, H.; Abu-Lebdeh, Y., On the Correlation between Free Volume, Phase Diagram and Ionic Conductivity of Aqueous and Non-Aqueous Lithium Battery Electrolyte Solutions over a Wide Concentration Range. J. Electrochem. Soc. 2017, 164, A1002-A1011. 
42. Newman, J.; Thomas-Alyea, K. E., Electrochemical Systems. 3rd ed.; John Wiley \& Sons: 2004.

43. Diederichsen, K. M.; McShane, E. J.; McCloskey, B. D., Promising Routes to a High $\mathrm{Li}^{+}$Transference Number Electrolyte for Lithium Ion Batteries. ACS Energy Lett. 2017, $2,2563-2575$.

44. Tokuda, H.; Hayamizu, K.; Ishii, K.; Abu Bin Hasan Susan, M.; Watanabe, M., Physicochemical Properties and Structures of Room Temperature Ionic Liquids. 1. Variation of Anionic Species. J. Phys. Chem. B 2004, 108, 16593-16600.

45. Stejskal, E. O.; Tanner, J. E., Spin Diffusion Measurements: Spin Echoes in the Presence of a Time-Dependent Field Gradient. J. Chem. Phys. 1965, 42, 288-292.

46. Sheldrick, G. M., SHELXT - Integrated Space-Group and Crystal-Structure Determination. Acta Crystallogr. Sect. A: Found. Crystallogr. 2015, 71, 3-8.

47. Sheldrick, G. M., Crystal Structure Refinement with SHELXL. Acta Crystallogr. Sect. C: Cryst. Struct. Commun. 2015, 71, 3-8. 


\section{TOC Graphic}

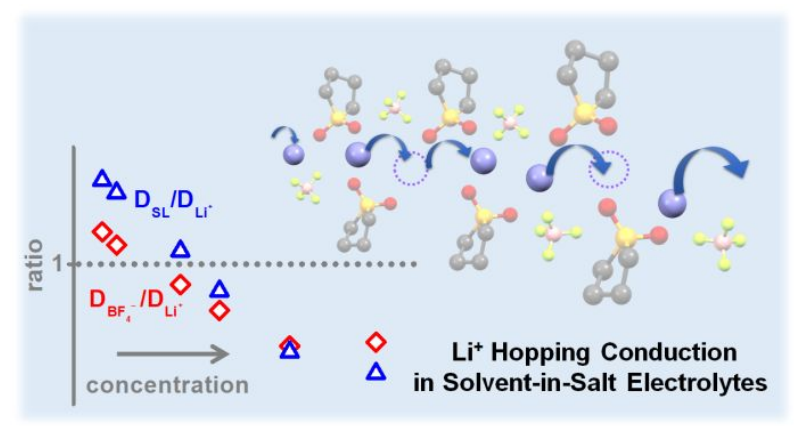

